\title{
Study of Remediation of Soil Contamined with Heavy Metals by Coal Fly Ash
}

\section{Elżbieta Sitarz-Palczak ${ }^{*}$, Jan Kalembkiewicz}

Department of Inorganic and Analytical Chemistry, Faculty of Chemistry, Rzeszów University of Technology, Rzeszów, Poland.

Email: *epalczak@prz.edu.pl

Received June $15^{\text {th }}, 2012$; revised July $18^{\text {th }}, 2012$; accepted August $21^{\text {st }}, 2012$

\begin{abstract}
The labile fraction of heavy metals in soils is the most important for toxicity for plants. Thus it is crucial to reduce this fraction in contamined soils to decrease the negative effect of heavy metals. In an experiment, the effects of two additives on the labile fractions of $\mathrm{Cu}, \mathrm{Mn}$ and $\mathrm{Zn}$ were investigated in a soil contamined during long-term application. The additive used was the coal fly ash. The treated soil was further enriched with heavy metals and allowed to age at room temperature for 30 days. After this period, they were extracted plant-available (EDTA; $\mathrm{HNO}_{3} ; \mathrm{CH}_{3} \mathrm{COOH}$ ) metal species. The addition of fly ash strongly reduced the plant-available of $\mathrm{Mn}$ for plants but to a lesser extent this applies to the plant-available of $\mathrm{Cu}$ and $\mathrm{Zn}$ for plants. By addition of $1 \%$ of fly ash as well as $2 \%$ of fly ash, the labile fraction of $\mathrm{Cu}, \mathrm{Mn}$ and $\mathrm{Zn}$ were lowered by $6.3,145.0$ and $29.7 \mathrm{mg} \cdot \mathrm{kg}^{-1}$, respectively. Moreover essential correlation between total $\mathrm{Cu}$ and $\mathrm{Zn}$ contents was stated in the soil with plant-available content of metals, with reference to both metals. Value of coefficients of correlation is attesting to it between the total and plant-available $\mathrm{Cu}$ and $\mathrm{Zn}$ contents which are respectively equal: $\mathrm{R}(\mathrm{Cu})=0.845, \mathrm{R}(\mathrm{Mn})=0.864$ and $\mathrm{R}(\mathrm{Zn})=0.872$ for $\mathrm{p}=99.5 \%$. The results suggested that leading into the soil of the additional amount of fly ash can be an effective way of chemical remediation with reference to soils contaminated by $\mathrm{Cu}$ or $\mathrm{Mn}$ or $\mathrm{Zn}$. Because he causes immobilization of examined heavy metals in the soil and in the process in the arrangement a - soil is limiting the availability of these metals plant and more distant bonds of the food chain.
\end{abstract}

Keywords: Soil Remediation; Heavy Metals; Coal Fly Ash; FAAS

\section{Introduction}

The main of the environmental problems in industrialized countries is the environmental impact, especially with heavy metals. Increased the concentration of heavy metals constitute a serious health threat of people and animals. Contamination with heavy metals can affect the whole environment, but the longest-lasting effects occur in the soils, on account of the absorption of many metals on mineral and organic colloids. Metals, unlike other pollutants, remain in the atomic form, although their speciation can change in the time together with changes in the soil conditions [1].

The long-lasting nature of contamination is dependent in the kind of the soil and its physicochemical properties. Removing heavy metals from the soil is a very difficult problem, because they are specific permanent pollution, which can in many causes data pack a few hundred or of even thousands of years [2]. It results from it the selfpurification processes are occurring in the soils very

\footnotetext{
"Corresponding author.
}

slowly [3]. Therefore, the contaminated soils should be recultivation, which in light of the applicable laws in Poland to lead to a reduction in the total content of pollutants in the soil to a state defined by standards of the quality of the soils and land [4].

On the review of work of available methods remediation that the next technical methods remediation that the next technical methods (ex-situ extraction [5,6], and insitu $[7,8]$, electrochemical methods [9-12], the use of zeolites [13-15]), also offer promising prospects phytoremediation methods, especially phytoextraction, involving the removal of pollutants from the soil, together with about-ground biomass of crops [16]. It seems that the treatment is sufficiently effective immobilization of heavy metals in the soil, effectively limiting their negative impact on the environment [17]. The immobilization is one of the chemical methods remediation of soils contaminated with heavy metals, consisting of heavy metals in an inaccessible form for plants, so their presence in the food chain is much lower, thus reducing the negative health and environmental effects. 
The availability of heavy metals to plants determined primarily by the $\mathrm{pH}$ of the soil, its granulometric composition and soil organic matter content [18]. It is well known that, the increased mobility of heavy metals is linked primarily to an excessive acidifications if soils. As a result, a significant acidification of soils, which increasing by anthropopressure, leading to accumulation in soils of excessive amounts of certain metal ions. This applies in particular metal ions such as $\mathrm{Cu}, \mathrm{Mn}, \mathrm{Zn}$, which are necessary for the proper functioning of living organisms, but their excess a shortage, a threat to these organisms. The determination of availability of heavy metals for plants is the soil sorption capacity determined quality and quantity of soil colloids forming absorbent complex. The sorption properties of soils are closely related to their buffer capacity and resistance to chemical pollution.

Based on the available literature, it appears that an effective way of contributing to the reduction of metal content in the available to plants forms is to improve the sorption of soils by providing a high content of organic matter while keeping of the high $\mathrm{pH}$ of soil. Above mentioned effect can be achieved through the use of various additives to the soil in the immobilization of heavy metals contained in the soil. These types of additives include for example lime [19,20], zeolites (both natural and artificially occurring in environment) [21,22], aluminosilicates and silicates $[23,24]$. An important supplementary source of organic matter in soil can also be brown coal and organic-mineral fertilizers from brown coal [25-27], phosphates and apatites $[20,28,29]$ and iron and manganese oxide bearing materials $[20,30]$. Each of these additives has a different effect on bio-availability of the metals, micronutrient availability, soil solution $\mathrm{pH}$ and soil microstructure $[20,21]$. Taking into account the content of organic matter and $\mathrm{pH}$ on the attention deserves also fly ash from coal combustion. Fly ash is the waste material of the composition of the dust. The positive impact of ash on the soil is due primarily by its chemical composition (low content of heavy metals, lack of radioactive element) [31]. The application of fly ashes from coal burning to the immobilization of heavy metals in relation to different types of soil and industrial wastes has been described in works [32-36].

On the light of the cited literature data it is reasonable to provide studied on the immobilization of selected heavy metals $(\mathrm{Cu}, \mathrm{Mn}$ and $\mathrm{Zn})$ using fly ash from coal combustion, whose purpose was to development of an effective, easily accessible and cheaper method of chemical remediation of comtamined soil of $\mathrm{Cu}, \mathrm{Mn}$ and $\mathrm{Zn}$. The scope done within of this study include: 1) determination of the total contents of $\mathrm{Cu}, \mathrm{Mn}$ and $\mathrm{Zn}$ in examined soil; 2) implementation of the soil tests based on single extractions for detemination of the plant available contents of
$\mathrm{Cu}, \mathrm{Mn}$ and $\mathrm{Zn} ; 3$ ) study of effect of fly ash from caoal burning on the availability of $\mathrm{Cu}, \mathrm{Mn}$ and $\mathrm{Zn}$ to plants; 4) examination of the possibility of using of fly ash as a chemical substance to support the chemical remediation of soils.

\section{Experimental}

\subsection{Apparatus}

The flame atomic absorption spectrometer Perkin-Elmer 3100 Model (Shelton Instruments, CT USA) was used for $\mathrm{Cu}, \mathrm{Mn}$ and $\mathrm{Zn}$ determination in the solutions. Measurements were performed at wavelength $324.8 \mathrm{~nm}(\mathrm{Cu})$, $279.5 \mathrm{~nm}(\mathrm{Mn})$ and $213.9 \mathrm{~nm}(\mathrm{Zn})$ using a yellow fuelrich air-acetylene flame (acetylene flow velocity 2.0 $\mathrm{dm}^{3} \cdot \mathrm{min}^{-1}$; air flow velocity $8.0 \mathrm{dm}^{3} \cdot \mathrm{min}^{-1}$ ) and burner height of $3 \mathrm{~mm}$. The analytical lines were selected using a slit width $0.7 \mathrm{~mm}(\mathrm{Cu}$ and $\mathrm{Zn})$ and $0.2 \mathrm{~mm}(\mathrm{Mn})$ [37]. Hollow cathode lamp at $10 \mathrm{~mA}(\mathrm{Cu}$ and $\mathrm{Zn}), 20 \mathrm{~mA}(\mathrm{Mn})$ was used. The centrifuge tube-test Model WE 1 (Precision Engineering, Poland) - was used for the centrifugation of the soil extracts at the speed of rotary at appropriate $3000 \mathrm{rpm}$. The universal laboratory shaker Vibramax 100 Model (Heidolph Instruments, Germany) and a hot plate HP 88720-26 Model (Barnstead/Thermolyne, USA) were used for the extraction. The $\mathrm{pH}$ of the extraction solutions was determined with a $\mathrm{pH}$ meter CPI-551 Model (Elmetron, Poland) supplied with a glass combination electrode.

\subsection{Reagents and Solutions}

All chemicals and reagents were of analytical grade or higher purity and were obtained from $\mathrm{POCH}$, Gliwice, Poland. The solutions were prepared by dissolving the appropriate compounds in double-distilled water from the Water Purification System (Rel-5 Model, MERAPOLNA, Poland). The reagents were prepared and stored in clean polyethylene bottles. Glassware and plasticware (PE) used throughout the experimental work were previously soaked in $10 \%$ nitric acid bath overnight and washed thoroughly in double distilled water.

Standard solutions were prepared from standard solutions for atomic absorption (Sigma-Aldrich Chemie $\mathrm{GmbH}$, Switzerland) $-\mathrm{Cu}$ concentration $1.000 \mu \mathrm{g} \cdot \mathrm{cm}^{-3}$ in $1 \%$ of $\mathrm{HNO}_{3}, \mathrm{Mn}$ concentration $1.000 \mu \mathrm{g} \cdot \mathrm{cm}^{-3}$ in $1 \%$ of $\mathrm{HNO}_{3}$ and $\mathrm{Zn}$ concentration $1.000 \mu \mathrm{g} \cdot \mathrm{cm}^{-3}$ in $1 \%$ of $\mathrm{HNO}_{3}$. Working standard solutions containing $\mathrm{Cu}, \mathrm{Mn}$ and $\mathrm{Zn}$ were prepared by serial dilution of the appropriately of standard solution for atomic absorption.

\subsection{Sample Collection and Preparation}

Coal fly ash samples used for the experiments were collected from the electric filter from Rzeszów S. A power- 
plant (Rzeszów, Poland). The $0.5 \mathrm{~kg}$ sample was prepared from overall air-dried $10 \mathrm{~kg}$ sample by a "quarterning" method-according to BN-81/0623-01 procedure [38]. After that, the air-dried ash was sieved, initially through a laboratory sieve of $1 \mathrm{~mm}$ diameter, and then milled in an agate mortar to fine powder $(\varphi \leq 100$ $\mu \mathrm{m}$ ) - according to PN-77/G-04528/00 [39].

The surface soil samples (depth: $0-15 \mathrm{~cm}$ ) were collected from the area of the permanent grassland from the field of 0.2 ha (the area of the University of Technology, Rzeszów, Poland) according to PN-R-04031 procedure [40]. The sample preparation was performed according to Namieśnik et al. [41]. The laboratory sample of the weight of about $0.5 \mathrm{~kg}$ was prepared by the "quarter" method from the general sample that weighted about 10.0 $\mathrm{kg}$, after getting it previously into the air-dried state in the laboratory conditions. The air-dried soil was sieved through a laboratory sieve with apertures of $1 \mathrm{~mm}$ and it was milled in an agate mortar to fine powder $(\varphi<100$ $\mu \mathrm{m})$.

\subsection{Procedures}

\subsubsection{Total Metal Determination}

Fly ash samples were digested in open PTFE $^{\circledR}$ vessels. $1.00 \mathrm{~g}$ of ash was digested with and mixture of $8 \mathrm{~cm}^{3}$ $65 \% \mathrm{HNO}_{3}, 4 \mathrm{~cm}^{3} 40 \% \mathrm{HF}, 2 \mathrm{~cm}^{3} 37 \% \mathrm{HCl}$ and $10 \mathrm{~cm}^{3}$ $\mathrm{H}_{2} \mathrm{O}$. After evaporating of liquids in a hot plane $(\mathrm{T}=$ $96^{\circ} \mathrm{C}$ ), the solution was replenished with water to $50 \mathrm{~cm}^{3}$, and $\mathrm{Cu}, \mathrm{Mn}$ and $\mathrm{Zn}$ was determined by the Flame Atomic Absorption Spectrometer (FAAS). The analysis of the total content of manganese in soil samples with concentrated $\mathrm{HF}$ and $\mathrm{HClO}_{4}$ acids was described in the work [42]. In the some way the analysis of the total content of $\mathrm{Cu}$ and $\mathrm{Zn}$ was performed in the examined soil. All samples were prepared in triplicates.

\subsubsection{Determination of Plant Available Content of Metal}

The determination of plant available content of cooper, manganese and zinc made the experience on which to test samples of soil were added specified volume of one of the following solutions: $0.05 \mathrm{~mol} \cdot \mathrm{dm}^{-3}$ EDTA, $2.5 \%$ $\mathrm{HOAc}$ and $1 \mathrm{~mol} \cdot \mathrm{dm}^{-3} \mathrm{HNO}_{3}$. The analytical procedure was identical in relation to all extraction solutions; weighed at $5.000( \pm 0.001) \mathrm{g}$ of tested soil samples, they were quantitatively transferred to bottles of PE and were added to $10 \mathrm{~cm}^{3}$ of one of the above solution, then were shaken on a laboratory shaker for about $2 \mathrm{~h}$. After this time the samples were filtered and/or centrifuged and completed of redistilled water in volumetric flask to volume $50 \mathrm{~cm}^{3}$. In the obtained solutions were determined the content of $\mathrm{Cu}, \mathrm{Mn}$ and $\mathrm{Zn}$ by FAAS method. In parallel with tested samples were prepared reagent blank (without soil) by entering the same quantities of reagents and by following the same steps as in the preparation of samples tested.

\subsubsection{Study of Effect of Fly Ash from Caoal Burning on the Availability of $\mathrm{Cu}, \mathrm{Mn}$ and $\mathrm{Zn}$ to Plants}

In order to determine the effect of fly ash on the availability of cooper, manganese and zinc for the plant performed an experiment in which to tested soil was added fly ash in an amount of $10 \%$ or $20 \%$ of the sample (which represents an increase of organic carbon in the tested soil respectively $1 \%$ or $2 \%$ ). In parallel with tested samples were prepared reagent blank (without fly ash) by entering the same quantities of reagents and performing the same steps as in the preparation of samples tested.

The prepared samples were left to dry (to the air-dry state) for about a week. After this time the samples were transferred quantitatively with $10 \mathrm{~cm}^{3}$ of $0.05 \mathrm{~mol} \cdot \mathrm{dm}^{-3}$ EDTA into a bottles of PE, and shaken on a laboratory shaker for $2 \mathrm{~h}$. After this time the samples were filtered and/or centrifuged and completed to the mark of redistilled water in volumetric flask with a capacity of $50 \mathrm{~cm}^{3}$. In the obtained solutions were determined the content of $\mathrm{Cu}, \mathrm{Mn}$ and $\mathrm{Zn}$ by FAAS method.

\subsubsection{Examination of the Possibility of Reducing the Availability of Metals to Plants under the Influence of Fly Ash}

In order to identify opportunities to reduce the availability of cooper, manganese and zinc for plants under the influence of fly ash made the experiment, which comprised following steps:

STAGE I-Preparation of working solutions of $\mathrm{Cu}$, $\mathrm{Mn}$ and $\mathrm{Zn}$

The following solutions were prepared: $\mathrm{CuCl}_{2}(10,25$, $\left.50,100,300 \mathrm{mg} \cdot \mathrm{kg}^{-1}\right) ; \mathrm{MnCl}_{2}(300,500,1000,1500$, $\left.3000 \mathrm{mg} \cdot \mathrm{kg}^{-1}\right)$ and $\mathrm{ZnCl}_{2}(50,100,150,300,1500$ $\left.\mathrm{mg} \cdot \mathrm{kg}^{-1}\right)$. The concentration of metals in this solutions are within in the limits of the content of soils polluted by industry and represent the highest doses similar to the permissible levels of these metals I soils.

\section{STAGE II-Analytical procedure}

The experiment was performed for three series of test samples, which contained the test soil brought into the dry air state in the laboratory conditions with the addition of fly ash (ash content $20 \%$ by mass of the sample):

Serie 1 -Convicted of solutions, which contained $\mathrm{Cu}$ at the concentrations respectively: 10, 25, 50, 100, 300 $\mathrm{mg} \cdot \mathrm{kg}^{-1}$;

Serie 2-Convicted of solutions, which contained $\mathrm{Mn}$ in concentration as following: $300,500,1000,1500$, $3000 \mathrm{mg} \cdot \mathrm{kg}^{-1}$;

Serie 3-Convicted of solutions containing $\mathrm{Zn}$ at the concentrations respectively: 50, 100, 150, 300, 1500 $\mathrm{mg} \cdot \mathrm{kg}^{-1}$. 
Series of tested samples were convicted for a period of four months with the solutions containing these metals in the mentioned above concentrations. After this time the tested samples were stabilized for about two weeks, moistening every two days with distilled water. Then left them to dry at room temperature in the laboratory conditions. After drying and homogenization the samples were griding in mortar (porcelain and agate), and then the samples were weighed after three representative samples, each of $5.000( \pm 0.001) \mathrm{g}$ within each series prepared. For each samples were added to $10 \mathrm{~cm}^{3}$ of EDTA at a concentrations $0.05 \mathrm{~mol} \cdot \mathrm{dm}^{-3}$ into the bottles of PE, and were shaken on the laboratory shaker for $2 \mathrm{~h}$. Then the samples were filtered and/or centrifuged, and completed to the mark in a volumetric flask with a capacity of $50 \mathrm{~cm}^{3}$. In the obtained solutions were performed to determine the content of $\mathrm{Cu}, \mathrm{Mn}$ and $\mathrm{Zn}$ by FAAS method. In parallel with the series of tested samples were prepared a control samples (without ash), introducing the same quantities of reagents and performing the same steps as in the preparation of tested samples.

The research was taken at the same time for six samples with simultaneously three-times repeated metal detection in each sample. Results presented are the mean of three replicates, passed the test for normality and were statistically analyzed by ANOVA test $(p=0.05)$. The statistical estimation of the results of analysis of metal content in soil, fly ash and soil with fly ash addition were carried out on the basis of a Student's t-test $(\mathrm{p}=95 \%)$. Statistical analysis were made using the STATISTICA 7.1. programme.

\section{Results and Discussion}

\subsection{Fly Ash Composition}

The results of the quantitative chemical analysis of the fly ash samples used are shown in Table 1. The results obtained (Table 1) suggest that in the studied ash the following oxides occur: $\mathrm{SiO}_{2}-42.9 \% ; \mathrm{Al}_{2} \mathrm{O}_{3}-20.8 \%$; $\mathrm{Fe}_{2} \mathrm{O}_{3}-6.3 \% ; \mathrm{CaO}-4.3 \% ; \mathrm{MgO}-3.5 \%$ (in calculation to the initial state). The content determined of major components (mentioned above), contained in the ash shows that the investigated fly ash can qualify as silicate ash, in which the content of major components averages respectively: $\mathrm{SiO}_{2}(40 \%-58 \%), \mathrm{Al}_{2} \mathrm{O}_{3}(15 \%-25 \%), \mathrm{Fe}_{2} \mathrm{O}_{3}$ (5\% - 15\%), $\mathrm{CaO}(2 \%-10 \%), \mathrm{MgO}(1 \%-5 \%)$ [43]. The content of other elements did not exceed $6 \%$ to the initial mass of ash.

\subsection{Soil Composition}

The main physical and chemical properties of the soil are shown in Table 2. Some general comments can be made about these characteristics of the soil samples. Based on the results obtained, it may be stated that the examined
Table 1. Total content of some elements in the fly ash (the results presented reflect values of data taken from 10 samples).

\begin{tabular}{ccc}
\hline $\begin{array}{c}\text { Components } \\
\text { of fly ash }\end{array}$ & $\begin{array}{c}\text { Content after } \\
\text { overheating in } \\
\text { temperature 815 }{ }^{\circ} \mathbf{C}\end{array}$ & $\begin{array}{c}\text { Content after calculation } \\
\text { on initial state }\end{array}$ \\
\hline $\mathrm{SiO}_{2}$ & 50.94 & 42.86 \\
$\mathrm{Al}_{2} \mathrm{O}_{3}$ & 24.74 & 20.81 \\
$\mathrm{Fe}_{2} \mathrm{O}_{3}$ & 7.52 & 6.33 \\
$\mathrm{CaO}$ & 5.12 & 4.31 \\
$\mathrm{MgO}$ & 4.12 & 3.47 \\
$\mathrm{Na}_{2} \mathrm{O}$ & 0.76 & 0.64 \\
$\mathrm{~K}_{2} \mathrm{O}$ & 3.08 & 2.59 \\
$\mathrm{SO}_{3}$ & 1.12 & 0.94 \\
$\mathrm{TiO}_{2}$ & 1.07 & 0.90 \\
$\mathrm{P}_{2} \mathrm{O}_{5}$ & 0.57 & 0.48 \\
$\mathrm{BaO}$ & 0.25 & 0.21 \\
$\mathrm{Mn}_{3} \mathrm{O}_{4}$ & 0.10 & 0.08 \\
$\mathrm{SrO}$ & 0.14 & 0.12 \\
calcination losses & - & 15.87 \\
$\mathrm{sum}$ & 99.53 & 99.61 \\
\hline
\end{tabular}

Table 2. Physical and chemical properties of the soil (the results presented denote values of data taken from 10 samples).

\begin{tabular}{cc}
\hline Parameter & Value of parameter \\
\hline $\mathrm{pH}_{\mathrm{H}_{2} \mathrm{O}}(1: 2.5)$ & 6.9 \\
$\mathrm{pH}_{\mathrm{KCl}}(1: 2.5)$ & 6.7 \\
$\mathrm{CaCO}_{3}(\%)$ & $<1.0$ \\
$\mathrm{O}_{\mathrm{M}}^{\mathrm{a}}{ }^{\mathrm{a}}(\%)$ & 1.2 \\
$\mathrm{C}_{\mathrm{org} .}(\%)$ & 0.7 \\
$\mathrm{CEC}^{\mathrm{b}}(\mathrm{meq} / 100 \mathrm{~g}$ soil) & 10.6 \\
SOIL TEXTURE (\%) & \\
$\mathrm{Clay}(0-2 \mu \mathrm{m})$ & 62.5 \\
$\mathrm{Silt}(2-50 \mu \mathrm{m})$ & 20.7 \\
Sand $(>50 \mu \mathrm{m})$ & 16.8 \\
$\mathrm{TEXTURAL}$ CLASS-LOESS & \\
\hline
\end{tabular}

${ }^{\mathrm{a}}$ Organic matter, ${ }^{\mathrm{b}}$ Cation exchange capacity.

soil (on account of value measured with the $\mathrm{pH}$ in $\mathrm{KCl}$ solution) could be included into neutral soils, of which the $\mathrm{pH}$ in $\mathrm{KCl}$ solution ranges from 6.6 - 7.2. The $\mathrm{pH}$ value is a determining factor on the mobility of trace metals in soil. In neutral soils, taking heavy metals by plants is in general smaller in comparison to strongly sour soils. The carbonate levels in the examined soil are low. The results obtained confirm the fact that in layers of surface soils the low carbonate levels account for the slightly alkaline or neutral character of the soil. The 
content of available forms of phosphorus, potassium and magnesium in the examined soil amounts respectively: $15.1 \mathrm{mg} \mathrm{P}_{2} \mathrm{O}_{5} / 100 \mathrm{~g} ; 13.3 \mathrm{mg} \mathrm{K} 2 \mathrm{O} / 100 \mathrm{~g}$ and $7.3 \mathrm{mg} \mathrm{Mg} /$ $100 \mathrm{~g}$ of dry mass of soil.

The investigated soil showed the granulometric compositions containing $62.5 \%$ clay fraction and $20.7 \%$ silt fraction. The fraction of sand is the smallest and it amounts to $16.8 \%$.

\subsection{Total Content of Metal}

Cooper is usually the strongly binding to surface level of soil and she does not migrate into the soil profile. However, due to the relatively high rate of bioaccumulation and high degree of anthropogenic its launch it is a risk of contamination if the local biological environment [18]. The content of $\mathrm{Cu}$ in the tested soil was equal to 39.9 $\mathrm{mg} \cdot \mathrm{kg}^{-1}$ dry mass of soil (Table 3). In the soils of the world the content of cooper falls between 1 to 140 $\mathrm{mg} \cdot \mathrm{kg}^{-1}$; in Poland, the average of its content in soil is $6.5 \mathrm{mg} \cdot \mathrm{kg}^{-1}$. However often assumed permissible limit of $\mathrm{Cu}$ in soils is $100 \mathrm{mg} \cdot \mathrm{kg}^{-1}$ [18]. The obtained results show that the mean content of $\mathrm{Cu}$ in the tested soil slightly deviates from the average for the $\mathrm{Cu}$ concentration in Polish soils, which may be related to the emission of dust particulate matter contains metals from industrial plants operating in the area where samples were collected.

Zinc is one of the mobility of metals in the soil, its accumulation in the surface levels of mineral and organic soil depends on the amount of organic matter, which creates a very stable bond with the metal. The higher plants usually take this element in proportion to its concentration in the soil, hence the bioavailability of $\mathrm{Zn}$ and the related risk of going into the food chain is significant because of the high solubility of compounds in which the element occurs. The concentration of $\mathrm{Zn}$ in the soil stood the test of $126.7-275.8 \mathrm{mg} \cdot \mathrm{kg}^{-1}$ dry mass of soil, with an average of $205.9 \mathrm{mg} \cdot \mathrm{kg}^{-1}$ dry mass of soil (Table 3). The content of $\mathrm{Zn}$ in soils on the world falls in the range of 150 to $400 \mathrm{mg} \cdot \mathrm{kg}^{-1}$; in Poland, the average content in soil of this element is $40 \mathrm{mg} \cdot \mathrm{kg}^{-1}$ [18]. The received, significantly increased the content of $\mathrm{Zn}$ in the studied soil may be due to the fast that zinc introduced into the soil as a result of agricultural or horticultural production is subject to the accumulation of surface soil levels.

The contamination of the soils manganese is associated with his form, rather than the quantity [44]. The content of $\mathrm{Mn}$ in soils of the world and Polish, depending on the type and nature of the soil, and it is located in the range from 100 to $1300 \mathrm{mg} \cdot \mathrm{kg}^{-1}$ [18]. In the analyzed soil the content of $\mathrm{Mn}$ fitted in range $283.8-413.1 \mathrm{mg} \cdot \mathrm{kg}^{-1}$ dry mass of soil, with an average of $347.9 \mathrm{mg} \cdot \mathrm{kg}^{-1}$ dry mass of soil (Table 3).

Among the studied heavy metals in the tested soil, it were found that showed the greatest variation in zinc content, and then manganese and cooper.

\subsection{Plant Available Content of Metal}

To the extraction of available forms of metal in soil used the weak extraction solutions; for example solutions of salt or weak acids, which are extracted from the soil the elements in small quantities, often only found in the soil solution. It is that is a good choice for assessing the forms available for plants to use intermediate solutions, which are extracted in addition to the forms present in the soil solution, including those that are potentially available to plants when soil conditions change. For this type of substances included in mineral acids $(\mathrm{HCl}$, $\mathrm{HNO}_{3}$ ), solutions of neutral salt or weak organic acids $\left(\mathrm{NH}_{4} \mathrm{OAc}, \mathrm{CaCl}_{2}, \mathrm{HOAc}\right)$ and chelate compounds (EDTA, DTPA).

The effects of extraction conditions on the result of determination of plant are available for $\mathrm{Cu}, \mathrm{Mn}$ and $\mathrm{Zn}$ in the soil. The soil was subjected to extraction using three extraction solutions $\left(0.05 \mathrm{~mol} \cdot \mathrm{dm}^{-3}\right.$ EDTA, $1 \mathrm{~mol} \cdot \mathrm{dm}^{-3}$ $\mathrm{HNO}_{3}, 2.5 \% \mathrm{HOAc}$ ); the results shown in Table 4. On the basis of obtained results were the effectiveness of the extraction specified, taking as a criterion the maximum amount of the metal extracted. It was found that the greatest amount of copper was extracted using 0.05 $\mathrm{mol} \cdot \mathrm{dm}^{-3}$ EDTA. By contrast, the zinc most efficient extraction solvent was a $1 \mathrm{~mol} \cdot \mathrm{dm}^{-3} \mathrm{HNO}_{3}$. The content of $\mathrm{Zn}$ available to plants obtained by using 0.05 $\mathrm{mol} \cdot \mathrm{dm}^{-3}$ EDTA was similar to values obtained using 1 $\mathrm{mol} \cdot \mathrm{dm}^{-3} \mathrm{HNO}_{3}$. For this reason in the course in further research to extraction of the content of $\mathrm{Zn}$ and $\mathrm{Cu}$ available to plants was $0.05 \mathrm{~mol} \cdot \mathrm{dm}^{-3}$ EDTA solution used. The same is the case with regard to the Mn content in the forms available to plants. The content of studied metals in the forms available to plants in telation to their total content depending on the type of extraction solutions used were showed on the Figures 1-3. It should be

Table 3. Total content of $\mathrm{Cu}, \mathrm{Mn}$ and $\mathrm{Zn}$ in the soil determined after total mineralization of soil using the FAAS method (concentration of metal in the soil and the confidence interval were given for $n=10$ at $p=95 \%$ ).

\begin{tabular}{ccccc}
\hline Total content of metal & Mean $\left[\mathrm{mg} \cdot \mathrm{kg}^{-1}\right]$ & Range $\left[\mathrm{mg} \cdot \mathrm{kg}^{-1}\right]$ & Standard deviation, SD & Coefficient of variation, CV [\%] \\
\hline $\mathrm{Cu}$ & $39.9( \pm 2.8)$ & $11.2-59.9$ & 58.4 & 41.4 \\
$\mathrm{Mn}$ & $347.9( \pm 19.0)$ & $283.8-413.1$ & 51.6 & 47.8 \\
$\mathrm{Zn}$ & $205.9( \pm 21.4)$ & $126.7-275.8$ & 18.6 & 52.9 \\
\hline
\end{tabular}


Table 4. Extraction solution type effect on the result of determination of plant available content of $\mathrm{Cu}, \mathrm{Mn}$ and $\mathrm{Zn}$ in the soil by the FAAS method (concentration of metal in soil and the confidence interval were given for $n=6$ at $p=95 \%$ ).

\begin{tabular}{cccc}
\hline \multirow{2}{*}{ Extraction solution } & \multicolumn{3}{c}{ Plant available content of metal $\left[{\left.\mathrm{mg} \cdot \mathrm{kg}^{-1}\right]}^{\mathrm{Zn}}\right.$} \\
\cline { 2 - 4 } & $\mathrm{Cu}$ & $\mathrm{Mn}$ & $45.5( \pm 2.9)$ \\
\hline $0.05 \mathrm{~mol} \cdot \mathrm{dm}^{-3} \mathrm{EDTA}$ & $9.6( \pm 0.9)$ & $145.0( \pm 1.8)$ & $50.0( \pm 3.1)$ \\
$1 \mathrm{~mol} \cdot \mathrm{dm}^{-3} \mathrm{HNO}_{3}$ & $5.9( \pm 1.2)$ & $158.0( \pm 2.5)$ & $25.0( \pm 1.8)$ \\
$2.5 \% \mathrm{CH}_{3} \mathrm{COOH}$ & $3.5( \pm 2.4)$ & $38.5( \pm 1.2)$ & $100-400$ \\
Phytotoxicity range for plants & $20-100$ & $400-1000$ & \\
\hline
\end{tabular}

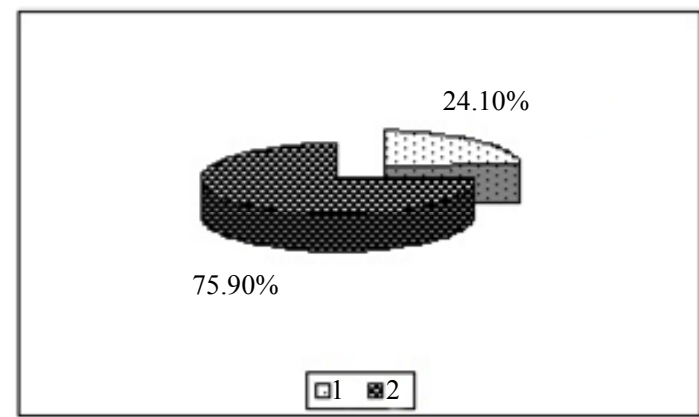

(a) EDTA

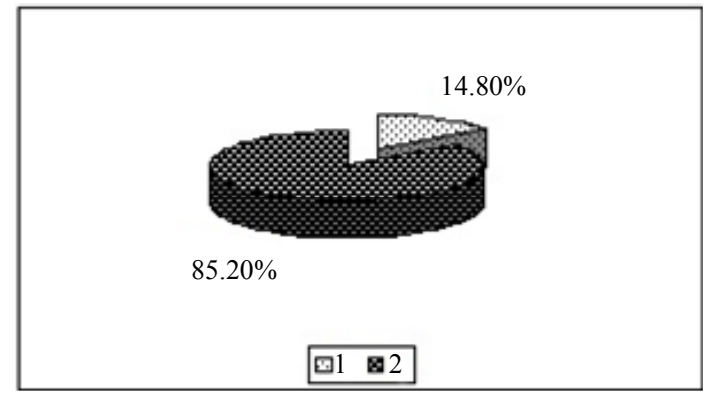

(b) $\mathrm{HNO}_{3}$

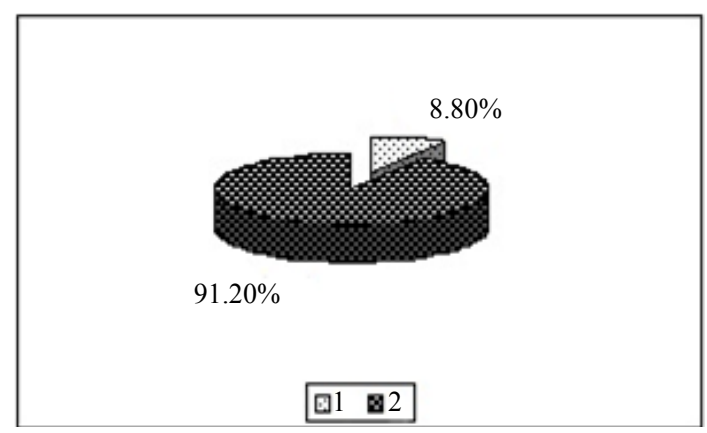

(c) HOAc

Figure 1. Content of copper in the forms available to plants [\%]. 1-In relation to total content of this element; 2 - In studied soil with no fly ash addition depending on the kind of extraction solution used.

emphasized high extraction efficiency of all tested metals, both highly active substances $\left(\mathrm{HNO}_{3}\right)$ as well as solutions of chelating salts (EDTA) and using a relatively low extraction solution that a weak acid (HOAc). The effectiveness of the extraction solutions used decreases in

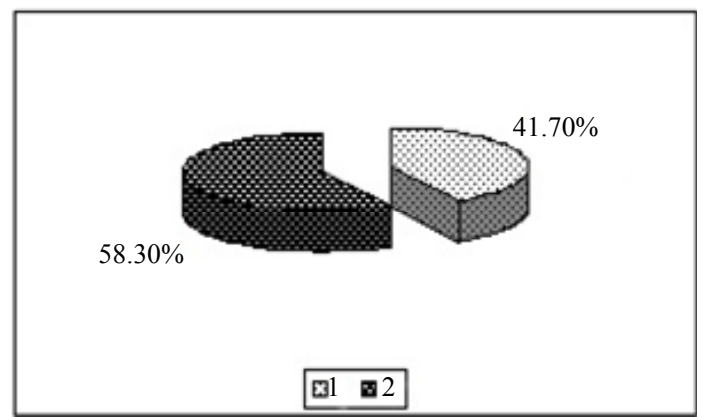

(a) EDTA

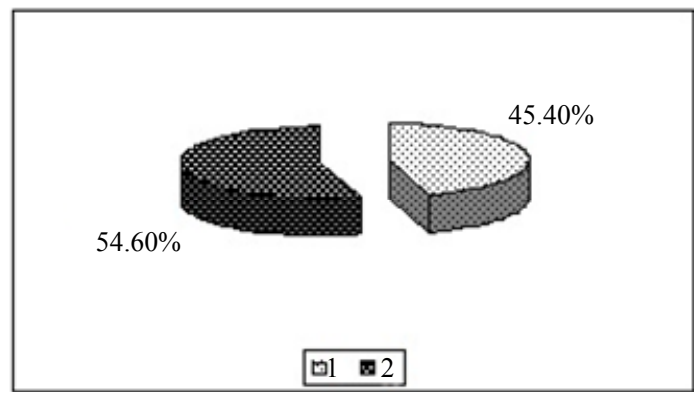

(b) $\mathrm{HNO}_{3}$

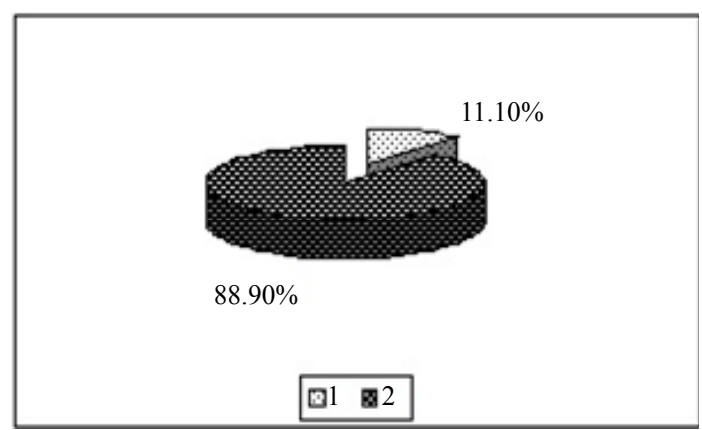

(c) HOAc

Figure 2. Content of manganese in the forms available to plants [\%]. 1-In relation to total content of this element; 2-In studied soil with no fly ash addition depending on the kind of extraction solution used.

the following series:

$\begin{array}{ll}\text { for } \mathrm{Cu} & \mathrm{EDTA}>\mathrm{HNO}_{3}>\mathrm{CH}_{3} \mathrm{COOH} \\ \text { for } \mathrm{Zn} & \mathrm{HNO}_{3}>\mathrm{EDTA}>\mathrm{CH}_{3} \mathrm{COOH} \\ \text { for } \mathrm{Mn} & \mathrm{HNO}_{3}>\mathrm{EDTA}>\mathrm{CH}_{3} \mathrm{COOH}\end{array}$

In conclusion, among the test solutions the most 


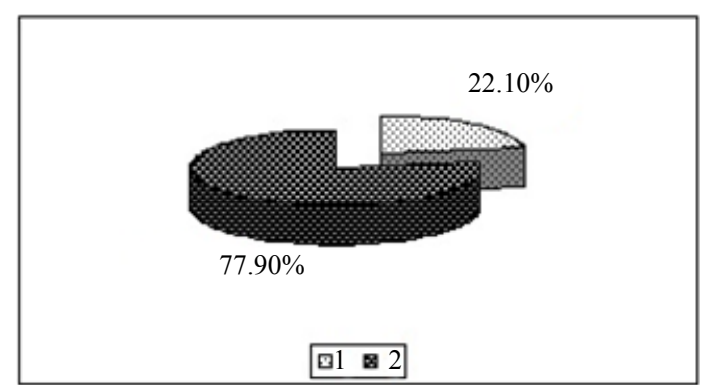

(a) EDTA

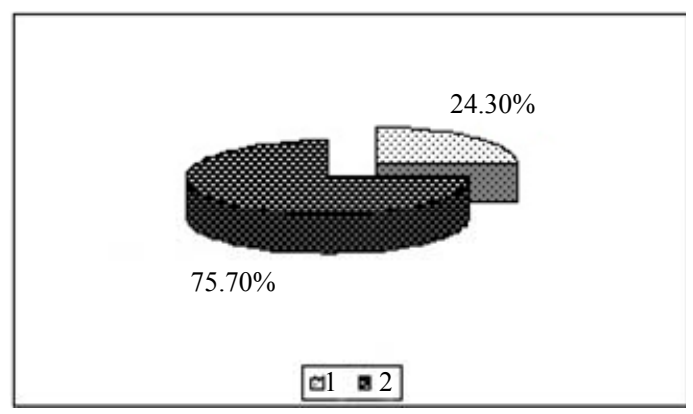

(b) $\mathrm{HNO}_{3}$

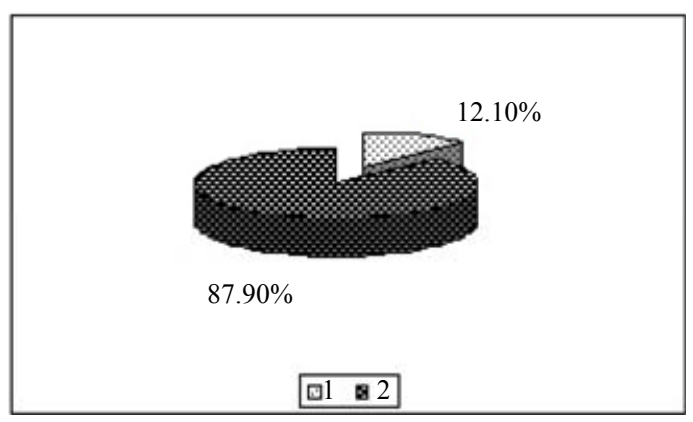

(c) HOAc

Figure 3. Content of zinc in the forms available to plants [\%]. 1-In relation to total content of this element; 2 - In studied soil with no fly ash addition depending on the kind of extraction solution used.

important role is played by extraction of EDTA, the undoubted advantage is that it is a good test for heavy metals extraction solvent, without destroying the mechanical structure in the soil and has relatively little effect on its biological activity. Moreover, based on available literature it is known that he has a very good correlation between the metal content in plants and extractable fraction [45-47]. The indicated concentration of $\mathrm{Cu}, \mathrm{Mn}$ and $\mathrm{Zn}$ within the scope of normal levels of these elements in plants and not exceed the phytotoxicity range for plants according to Kabata-Pendias [18] (Table 4). The interpretation of the obtained results in studied on plant available forms of cooper, manganese and zinc is difficult because the content of these forms, only inform us about the possibility of download these elements by plants at the time of the analysis. Just change the total content of these metals in the soil that the bioavailability of this has completely changed. In addition, the content of the analyzed elements in the forms available to plants is highly dependent on the physicochemical properties of tested soil, mainly from its $\mathrm{pH}$, granulometric composition and on the abundance of soil in humus.

Taking into account the results of statistical analysis, found a significant correlation between the total content of $\mathrm{Cu}, \mathrm{Mn}$ and $\mathrm{Zn}$ in soil and the plant available content of this metals. Testify to the value of the correlation coefficients between total and available to plants content of $\mathrm{Cu}, \mathrm{Mn}$ and $\mathrm{Zn}$, which were respectively equal to: $\mathrm{R}(\mathrm{Cu})=0.845, \mathrm{R}(\mathrm{Mn})=0.864$ i $\mathrm{R}(\mathrm{Zn})=0.872$ dla $\mathrm{p}=$ 0.05 . There was not significant relationship between the content of $\mathrm{Cu}, \mathrm{Mn}$ and $\mathrm{Zn}$ in the forms available to plants and the $\mathrm{pH}$ values or physico-chemical parameters of the tested soil. This should be attributed to too small sample subjected to statistical analysis within which the distribution of property different from the normal distribution.

\subsection{Study of the Impact of Fly Ash on the Availability of Metals to Plants}

The important source of organic matter in soil may be fly ashes from coal combustion. Their influence on the content of $\mathrm{Cu}, \mathrm{Mn}$, and $\mathrm{Zn}$ in the available to plants forms are shown in Table 5. As can be seen from the data presented in Table 5, independently whether the tested soil was added $1 \%$ or $2 \%$ ash in calculation of organic carbon $\left(\mathrm{C}_{\text {org }}\right)$ were obtained identical results with regard to the contents of individual metals in the available to plants forms. This can be explained by the fact that the obtained results are adequate for the time at which the analysis was performed. From the results in this table shows that, the addition to tested soil the fly ash was significantly $\mathrm{Zn}$ and $\mathrm{Cu}$ immobilized and

Table 5. Fly ash addition influence on the determination result of the plant available content of $\mathrm{Cu}, \mathrm{Mn}$ and $\mathrm{Zn}$ $\left[\mathrm{mg} \cdot \mathrm{kg}^{-1}\right]$ in the soil obtained by extraction method by 0.05 mol/dm ${ }^{3}$ EDTA and the FAAS method application (concentration of metal in the soil and the confidence interval were given for $n=6$ at $p=95 \%$ ).

\begin{tabular}{ccc}
\hline Element & $\begin{array}{c}\text { Amount of added fly ash in } \\
\text { calculation on } \mathrm{C}_{\text {org }}[\%]\end{array}$ & $\begin{array}{c}\text { Plant available content of } \\
\text { metal }\left[\mathrm{mg} \cdot \mathrm{kg}^{-1}\right]\end{array}$ \\
\hline \multirow{3}{*}{$\mathrm{Cu}$} & non-addition & $9.6( \pm 0.9)$ \\
& 1 & $6.3( \pm 1.8)$ \\
$\mathrm{Mn}$ & 2 & $6.3( \pm 2.4)$ \\
& non-addition & $145.0( \pm 1.8)$ \\
& 1 & $6.5( \pm 0.7)$ \\
$\mathrm{Zn}$ & 2 & $6.5( \pm 1.2)$ \\
& non-addition & $45.5( \pm 2.9)$ \\
& 1 & $29.7( \pm 3.2)$ \\
& 2 & $29.7( \pm 2.9)$ \\
\hline
\end{tabular}


thereby reduced the availability of tested metals from plants. Namely, without the addition of ash the content of $\mathrm{Cu}$ in the forms available to plants is around $24.1 \%$ in relation to the total content, while in soil with ash about $15.8 \%$. For manganese, they are respectively $47.7 \%$ and $1.9 \%$; while for zinc are equal to respectively $22.1 \%$ and $14.4 \%$. With regard to the tested metals was found, that ash is an effective factor in limiting the availability of various metals to plants in the following degrees: $\mathrm{Cu}$ (8.3\%), Mn (39.8\%) and Zn (7.7\%). The immobilization of tested metals decreases in the following series: $\mathrm{Mn}>$ $\mathrm{Cu}>\mathrm{Zn}$.

In conclusion, the components of fly ash show a great affinity for the formation of insoluble connections tested heavy metals. The presence of these connections will the immobilization of heavy metals in soil and consequently reduce the availability of these metals to plants, and reduce their content in the system soil-plant and downstream tropic chain. The observed fact, that the use of the certain doe of fly ash can be effectively investigated immobilization of heavy metals have a direct practical importance. This means that, the fly ash used in experiment can be taken into account, as a supplement for the remediationof soils contamined with $\mathrm{Cu}, \mathrm{Mn}$ or $\mathrm{Zn}$.

\subsection{Investigation of the Possibilities of Reduced the Availability of Metals to Plants under the Influence of Fly Ash}

The results of a study on the possibility of limiting the availability of $\mathrm{Cu}, \mathrm{Mn}$ and $\mathrm{Zn}$ to plants under the influence of fly ash are given in Table 6. Based on the obtained results found, that the available to plants content of $\mathrm{Cu}$ respectively averaged $17.9 \%, \mathrm{Mn}-38.8 \%$ and $\mathrm{Zn}$ $17.2 \%$ in relation to the total content in the soil without the addition of fly ash. In turn, after addition of ash to soil, the content of examined metals in the forms available to plants are respectively: $\mathrm{Cu}-12 \%, \mathrm{Mn}-1.7 \%$ i $\mathrm{Zn}-16 \%$ (Table 6). This indicates for a reduction of the content of metal available to plants in the range of concentrations, respectively for $\mathrm{Cu}\left(10-300 \mathrm{mg} \cdot \mathrm{kg}^{-1}\right)$, for Mn (300 - $\left.3000 \mathrm{mg} \cdot \mathrm{kg}^{-1}\right)$ and $\mathrm{Zn}\left(50-500 \mathrm{mg} \cdot \mathrm{kg}^{-1}\right)$, after the addition of fly ash in an amount of $2 \%$ in terms of organic carbon $\left(\mathrm{C}_{\text {org }}\right)$. The reduction of concentrations of tested metals in the forms available to plants when added to soil fly ash was due to an increase in soil $\mathrm{pH}$ and the introduction in the environmental soil of additional ions $\left(\mathrm{Ca}^{2+}, \mathrm{Mg}^{2+}, \mathrm{K}^{+}, \mathrm{Na}^{+}\right)$. The concentration of these ions determines the sorption capacity of soil, which determines the degree of retention the heavy metals by the soil. The addition of fly ash reduces the availability of $\mathrm{Mn}$ to the greatest extent (37.1\%), to a lesser extent $\mathrm{Cu}(5.9 \%)$ and lowest $\mathrm{Zn}(1.2 \%)$. Obviously coal fly ash was less effective for immobilization of $\mathrm{Zn}$ compared $\mathrm{Cu}$ and $\mathrm{Mn}$. This is due to greater affinity for $\mathrm{Mn}$ and $\mathrm{Cu}$ complexes in the soil and create lasting relationships with them. In turn, $\mathrm{Zn}$ does not show a large affinity for the complex compounds and the tendency to form lasting relationships with them.

Table 6. Plant available content of $\mathrm{Cu}, \mathrm{Mn}$ and $\mathrm{Zn}\left[\mathrm{mg} \cdot \mathrm{kg}^{-1}\right]$ recovered after 30 days from metal addition to the soil obtained by extraction with $0.05 \mathrm{~mol} / \mathrm{dm}^{3}$ EDTA and by the FAAS method (concentration of metal in the soil and the confidence interval were given for $n=6$ at $p=95 \%$ ).

\begin{tabular}{|c|c|c|c|c|c|}
\hline \multirow{2}{*}{ Metal } & \multirow{2}{*}{$\begin{array}{l}\text { Total content of metal } \\
\text { in soil }\left[\mathrm{mg} \cdot \mathrm{kg}^{-1}\right]\end{array}$} & \multirow{2}{*}{$\begin{array}{l}\text { Metal addition to } \\
\text { soil }\left[\mathrm{mg} \cdot \mathrm{kg}^{-1}\right]\end{array}$} & \multirow{2}{*}{$\begin{array}{l}\text { Summary concentration } \\
\text { of metal in soil }\left[\mathrm{mg} \cdot \mathrm{kg}^{-1}\right]\end{array}$} & \multicolumn{2}{|c|}{ Plant available content of metal } \\
\hline & & & & Non-addition of fly ash $\left[\mathrm{mg} \cdot \mathrm{kg}^{-1}\right]$ & With-addition of fly ash $\left[\mathrm{mg} \cdot \mathrm{kg}^{-1}\right]$ \\
\hline \multirow{5}{*}{$\mathrm{Cu}$} & \multirow{5}{*}{$39.9( \pm 2.8)$} & 10 & 49.9 & 7.2 & 5.5 \\
\hline & & 25 & 64.9 & 12.3 & 6.5 \\
\hline & & 50 & 89.9 & 17.1 & 11.7 \\
\hline & & 100 & 139.9 & 25.2 & 19.6 \\
\hline & & 300 & 339.9 & 64.6 & 40.8 \\
\hline \multirow{5}{*}{$\mathrm{Mn}$} & \multirow{5}{*}{$347.9( \pm 19.0)$} & 300 & 647.9 & 223.0 & 11.2 \\
\hline & & 500 & 847.9 & 350.3 & $13 . .8$ \\
\hline & & 1000 & 1347.9 & 541.7 & 22.1 \\
\hline & & 1500 & 1847.9 & 729.8 & 34.5 \\
\hline & & 3000 & 3347.9 & 1295.3 & 62.6 \\
\hline \multirow{5}{*}{$\mathrm{Zn}$} & \multirow{5}{*}{$205.9( \pm 21.4)$} & 50 & 255.9 & 43.5 & 42.8 \\
\hline & & 100 & 305.9 & 52.0 & 46.2 \\
\hline & & 150 & 355.9 & 60.5 & 55.1 \\
\hline & & 300 & 505.9 & 91.1 & 85.5 \\
\hline & & 1500 & 1705.9 & 290.1 & 266.3 \\
\hline
\end{tabular}


In the interpretation of results must take into account that the behavior of heavy metals after their introduction into the soil is determined by two groups opposing processes. The first includes processes that reduce the mobility of a given element and its accumulation in the superficial layers of the soil. These are primarily ions sorption by mineral and organic absorbent complex of soil, precipitation of insoluble compounds from the soil solution and the biogenic accumulation. The second group consists of processes that increase the mobility of elements, and thus desorption, solubility and mineralization of organic compounds. Solubility and desorption of $\mathrm{Cu}, \mathrm{Mn}$, $\mathrm{Zn}$ increased with a decrease in $\mathrm{pH}$, hence the intensity of the start of these metals in acidic soils is several times higher than in soils with $\mathrm{pH}$ neutral or slightly acid. The degree of mobility of metal is also studied closely with the type of soil, as well, as their geochemical properties.

\section{Conclusion}

The issue related to the remediation of contaminated soils is difficult and requires a systematic research aimed at developing the most effective, cheapest and most readily available methods. The proposed method using the coal fly ash to the immobilization of heavy metals is technically easy to implement. It can be an effective means of chemical remediation for soils contamined with $\mathrm{Cu}$ (concentration range $10-300 \mathrm{mg} \cdot \mathrm{kg}^{-1}$ ), $\mathrm{Mn}(300-$ $\left.3000 \mathrm{mg} \cdot \mathrm{kg}^{-1}\right)$ or $\mathrm{Zn}\left(50-500 \mathrm{mg} \cdot \mathrm{kg}^{-1}\right)$. The most important advantage of this method is the fact, that can be applied to large areas due to non-toxic properties of fly ash. In addition, is an effective way to use fly ashes from coal, which the quantity from year to year systematicaly increases. Nevertheless, one must ask whether the effect if immobilization of tested heavy metals will be sustainable in a environment?

\section{REFERENCES}

[1] B. J. Alloway, "Heavy Metals in Soils," John Wiley \& Sons, New York, 1990.

[2] B. J. Alloway and D. C. Ayres, "Chemical Principles of Environmental Pollution," 2nd Edition, Blackie Academic \& Professional (Chapman \& Hall), London, 1997, pp. 205- 211.

[3] A. Bradshaw, "The Use of Natural Processes in Reclamation-Advantages and Difficulties," Landscape and Urban Planning, Vol. 51, No. 2-4, 2000, pp. 89-100. doi:10.1016/S0169-2046(00)00099-2

[4] "The Regulation on Minister of Environment of 9 September 2002 r. on the Quality Standards for Soil and Land-Dz. U. Nr 165, poz. 1359," Polish Ministry of Environment, Varsov, 2002.

[5] S. Tandy, K. Bossart, R. Mueller, J. Ritschel, L. Hauser, R. Schulin and B. Nowack, "Extraction of Heavy Metals from Soils Using Biodegradable Chelating Agents," En- vironmental Science \& Technology, Vol. 38, No. 3, 2004 pp. 937-944. doi:10.1021/es0348750

[6] G. M. Hettiarachchi, G. M. Pierzynski and M. D. Ransom, "In Situ Stabilization of Soil Lead Using Phosphorus and Manganese Oxide," Environmental Science \& Technology, Vol. 34, No. 21, 2000, pp. 4614-4619. doi:10.1021/es001228p

[7] E. Lombi, R. E. Hamon, S. P. McGrath and M. J. McLaughlin, "Lability of $\mathrm{Cd}, \mathrm{Cu}$ and $\mathrm{Zn}$ in Polluted Soils Treated with Lime, Beringite, and Red Mud and Identification of a Non-Labile Colloidal Fraction of Metals Using Isotopic Techniques," Environmental Science \& Technology, Vol. 37, No. 5, 2003, pp. 979-984. doi:10.1021/es026083w

[8] G. Heron, M. Van Zutphen, T. H. Christensen and C. G. Enfield, "Soil Heating for Enhanced Remediation of Chlorinated Solvents: A Laboratory Study on Resistive Heating and Vapor Extraction in a Silty, Low-Permeable Soil Contaminated with Trichloroethylene," Environmental Science \& Technology, Vol. 32, No. 10, 1998, pp. 1474 1481. doi:10.1021/es970563j

[9] S. I. Wada and Y. Umegaki, "Major Ion and Electrical Potential Distribution in Soil under Electrokinetic Remediation," Environmental Science \& Technology, Vol. 35, No. 11, 2001, pp. 2151-2155. doi:10.1021/es001335j

[10] J. Singh, S. D. Comfort and P. J. Shea, "Iron-Mediated Remediation of RDx-Contaminated Water and Soil under Controlled Eh/Ph," Environmental Science \& Technology, Vol. 33, No. 9, 1999, pp. 1488-1494. doi:10.1021/es9806175

[11] M. O. Oyanader, P. E. Arce and A. Dzurik, "Design Criteria for Soil Cleaning Operations in Electrokinetic Remediation: Hydrodynamic Aspects in an Annular Geometry," Industrial \& Engineering Chemistry Research, Vol. 44, No. 16, 2005, pp. 6200-6211. doi:10.1021/ie049045p

[12] L. Zhongming, Y. Ji-Wei and N. Ivars, "Electroremediation: Removal of Heavy Metals from Soils by Using Cation Selective Membrane," Environmental Science \& Technology, Vol. 32, No. 3, 1998, pp. 394-397. doi:10.1021/es9703584

[13] Y. L. Wei, Y. W. Yang and N. Cheng, "Study of Thermally Immobilized $\mathrm{Cu}$ in Analogue Minerals of Contaminated Soils," Environmental Science \& Technology, Vol. 35, No. 2, 2001, pp. 416-421. doi:10.1021/es0008721

[14] W. Y. Shi, H. Shao, H. Li, M. Shao and S. Du, "Progress in the Remediation of Hazardous Heavy Metal-Polluted Soils by Natural Zeolite," Journal of Hazardous Materials, Vol. 170, No. 1, 2009, pp. 1-6. doi:10.1016/j.jhazmat.2009.04.097

[15] B. Lothenbach, G. Furrer, H. Scharli and R. Schulin, "Immobilization of Zinc and Cadmium by Montmorillonite Compounds: Effects of Aging and Subsequent Acidification," Environmental Science \& Technology, Vol. 33, No. 17, 1999, pp. 2945-2952. doi:10.1021/es981317q

[16] B. Kos and D. Lestan, "Induced Phytoextraction/Soil Washing of Lead Using Biodegradable Chelate and Permeable Barriers," Environmental Science \& Technology, 
Vol. 37, No. 3, 2003, pp. 624-629. doi:10.1021/es0200793

[17] A. Kabata-Pendias, M. Piotrowska and T. Witek, "Evaluation of the Quality and Capabilities of Agricultural Use of Soils Contamined with Heavy Metals," Soil Science and Plant Institute, Puławy, 1993.

[18] A. Kabata-Pendias and H. Pendias, "Biogeochemistry of Trace Elements," Polish Scientific Publishing Company, Varsov, 1999

[19] A. Badora, G. Furrer, A. Grünwald and R. Schulin, "Immobilization of Zinc and Cadmium in Polluted Soils by Polynuclear $\mathrm{Al}_{13}$ and and Al-Montmorillonite," Journal of Soil Contamination, Vol. 7, No. 5, 1998, pp. 573-588.

[20] M. Mench, J. Vangronsveld, N. Lepp and R. Edwards, "Physicochemical Aspects and Efficiency of Trace Element Immobilization by Soil Amendments," In: J. Vangronsveld and S. Cunningham, Eds., Metal-Contaminated Soils: In-Situ Inactivation and Phytorestoration, Springer Verlag and Landes Bioscience, New York, 1998, pp. 151182.

[21] L. A. Oste, T. M. Lexmond and W. H. Van Riemsdijk, "Metal Immobilization in Soils Using Synthetic Zeolites," Journal of Environmental Quality, Vol. 31, No. 3, 2002, pp. 813-821. doi:10.2134/jeq2002.0813

[22] B. Gworek, "Inactivation of Cadmium in Contaminated Soil Using Synthetic Zeolites," Environmental Pollution, Vol. 75, No. 3, 1992, pp. 269-271. doi:10.1016/0269-7491(92)90126-U

[23] I. Corrales, P. Barcelo and J. Barcelo, "Influence of Silicon Pretreament on Aluminum Toxicity in Maize Roots," Plants and Soil, Vol. 190, No. 2, 1997, pp. 203-209. doi:10.1023/A:1004209828791

[24] A. Badora, "Aluminium Solubility in the Presence of Citric Acid," Advances of Agricultural Sciences Problem Issues, Polish Academy of Sciences, Varsov, 1998, pp. 197-201.

[25] A. Karczewska, T. Chodak and J. Kaszubkiewicz, "The Suitability of Brown Coal as a Sorbent for Heavy Metals in Polluted Soils," Applied Geochemistry, Vol. 11, No. 1-2, 1996, pp. 343-346. doi:10.1016/0883-2927(95)00043-7

[26] A. Maciejewska, "An Organic-Mineral Fertilizer from Brown Coal Applied to Soil Decreases Cadmium, Lead and Zinc Concentrations in Plants. Understanding and Managing Organic Matter in Soils," Sediments and Waters, Vol. 44, No. 3, 2001, pp. 517-523.

[27] A. Maciejewska, "Study of the Properties and Fertility of Sandy Soil after the Use of Unconventional Fertilizer Obtained from Lignite," Acta Academic Agricultural Technical Academy Olsztyn, Agricultural Academy Olsztyn, 1994, pp. 1-67.

[28] V. Laperche, S. J. Traina, P. G. Gaddam and T. J. Logan, "Chemical and Mineralogical Characterization of $\mathrm{Pb}$ in Contamined Soil. Reactions with Apatite," Environmental Science \& Technology, Vol. 30, No. 11, 1996, pp. 33213326. doi:10.1021/es960141u

[29] J. Boisson, A. Ruttens, M. Mench and J. Vangronsveld, "Evaluation of Hydroxyapatite as a Metal Immobilizing
Soil Additive for the Remediation of Polluted Soils. Part 1. Influence of Hydroxyapatite on Metal Exchangeability in Soil, Plant, Growth and Plant Metal Accumulation," Environmental Pollution, Vol. 104, No. 2, 2005, pp. 225233doi:10.1016/S0269-7491(98)00184-5.

[30] M. Mench, J. Vangronsveld, V. Didier and H. Clijsters, "Evaluation of Metal Mobility, Plant Availability and Immobilization by Chemical Agents in a Limed-Silty Soil," Environmental Pollution, Vol. 86, No. 3, 1994, pp. 279-286. doi:10.1016/0269-7491(94)90168-6

[31] R. Mohapatra and J. R. Rao, "Some Aspects of Characterisation, Utilisation and Environmental Effects of Fly Ash (a Review)," Journal of Chemical Technology \& Biotechnology, Vol. 76, No. 1, 2001, pp. 9-26. doi:10.1002/1097-4660(200101)76:1<9::AID-JCTB335> 3.0.CO;2-5

[32] C. Fernández-Pereira, Y. L. Galiano, M. A. RodriguezPiňero, J. Vale and X. Querol, "Utilisation of Zeolitised Coal Fly Ash as Immobilizing Agent of a Metallurgical Waste," Journal of Chemical Technology \& Biotechnology, Vol. 77, No. 16, 2002, pp. 305-310. doi: $10.1002 /$ jctb. 584

[33] M. Polat, E. Lederman, J. Pelly and H. Cohen, "Chemical Neutralization of Acidic Wastes Using Fly Ash in Israel," Journal of Chemical Technology \& Biotechnology, Vol. 77, No. 3, 2002, pp. 377-381. doi:10.1002/jctb.567

[34] T. Matsi and V. Z. Keramidas, "Fly Ash Application on Two Acid Soils and Its Effect on Soil Salinity, pH, B, P and Ryegrass Growth and Composition," Environmental Pollution, Vol. 104, No. 1, 1999, pp. 107-112. doi:10.1016/S0269-7491(98)00145-6

[35] R. Ciccu, M. Ghiani, A, Serci, S. Fadda, R. Peretti and A. Zucca, "Heavy Metal Immobilization in the MiningContaminated Soils Using Various Industrial Wastes," Minerals Engineering, Vol. 16, No. 3, 2003, pp. 187-192. doi:10.1016/S0892-6875(03)00003-7

[36] X. Querol, A. Alastuey, N. Moreno, E. Alvarez-Ayuso, A. García-Sánchez, J. Cama, C. Ayora and M. Simón, "Immobilization of Heavy Metals in Polluted Soils by the Addition of Zeolitic Material Synthesized from Coal Fly Ash," Chemosphere, Vol. 62, No. 2, 2006, pp. 171-180. doi:10.1016/j.chemosphere.2005.05.029

[37] The Perkin-Elmer Corporation, "Analytical Methods for Atomic Absorption Spectrophotometry," Norwalk Connecticut, USA, 1982. doi:10.1016/0010-4485(82)90253-6

[38] Polish Branch Standard BN-81/0623-01, "Fly Ashes and Slags from Kettles Heated with Hard and Brown Coal," Polish Committee for Standardization, Varsov, 1982.

[39] Polish Standard PN-77/G-04528/00, "Solid Fuels. Determination of Chemical Composition of Ash," Preparation of Ash Sample and Solution for Testing.

[40] Polish Standard PN-R-04031, "Agrochemical Soil analyses," Sampling.

[41] J. Namieśnik, Z. Jamrógiewicz, M. Pilarczyk and L. Torres, "The Preparation of Environmental Samples for Analysis," Publishing Company of Science and Technology, Varsov, 2000.

[42] J. Kalembkiewicz and E. Sitarz-Palczak, "Optimization of 
Mineralization Procedures for the Determination of $\mathrm{Mn}$ in Soil Samples," Atomic Spectroscopy, Vol. 22, No. 6, 2001, pp. 433-437.

[43] M. J. Łączny, "Non-conventional Method of Utilization of Fly Ash," Central Mining Institute, Katowice, 2002, pp. 7-19.

[44] J. Kalembkiewicz, E. Sitarz-Palczak and L. Zapała, "A Study of the Chemical Forms or Species of Manganese Found in Coal Fly Ash and Soil," Microchemical Journal, Vol. 90, No. 1, 2008, pp. 37-43. doi:10.1016/j.microc.2008.03.003

[45] J. B. Diatta, "Comparison if $\mathrm{NH}_{4} \mathrm{OAc}$ and $\mathrm{NH}_{4}$-EDTA Differing in Concentration and $\mathrm{pH}$ for $\mathrm{Cu}$ and $\mathrm{Zn}$ Extrac- tion in Soils Contamined by a Cooper Smelter," Polish Journal of Soil Science, Vol. 31, No. 1, 1998, pp. 25-32.

[46] Y. B. Ma and N. C. Uren, "Transformations of Heavy Metals Added to Soil-Application of a New Sequential Extraction Procedure," Geoderma, Vol. 84, No. 1-3, 1998, pp. 157-168. doi:10.1016/S0016-7061(97)00126-2

[47] M. J. Sánchez-Martin, M. Garcia-Delgado, L. F. Lorenzo, M. S. Rodriguez-Cruz and M. Arienzo, "Heavy Metals in Sewage Sludge Amended Soils Determined by Sequential Extractions as a Function of Incubation Time of Soils," Geoderma, Vol. 142, No. 3-4, 2007, pp. 262-273. doi:10.1016/j.geoderma.2007.08.012 